\title{
AUTISMO INFANTIL EM MANCHETES DE REVISTAS PARA PAIS E MÃES
} Pôster

Autores deste trabalho:

Raissa Freitas Gomes Brito: Universidade de Fortaleza (UNIFOR)

Mirna Albuquerque Frota: Universidade de Fortaleza (UNIFOR)

Área do Trabalho: Psicologia Infantil

Data da submissão: 23/07/2018 às 19h53min

\section{Justificativa}

Dados de estudos epidemiológicos sobre o Transtorno do Espectro Autista (TEA) indicando, na última década, aumento drástico na prevalência entre crianças (1-2\%) apontam para a importância do reconhecimento precoce do transtorno. Nesse contexto, a mídia, enquanto influente meio de comunicação de massa e transmissão de ensinamentos, tem papel diferenciado. Pesquisar o que é publicado, por exemplo, em revistas de circulação nacional, tendo em vista o número de leitores influenciados, permite-nos, portanto, ampliar a compreensão acerca das concepções vigentes sobre o tema.

\section{Objetivo(s)}

Analisar o conteúdo que revistas de circulação nacional voltada para pais e mães, com foco no desenvolvimento infantil, têm publicado sobre o Transtorno do Espectro Autista.

\section{Método(s)}

Trata-se de uma pesquisa documental, de abordagem qualitativa, realizada em notícias veiculadas na internet, no período de julho de 2013 a julho de 2018, no site das revistas Crescer e Pais \& Filhos, que continham, em suas manchetes, o termo "autismo" ou seus derivados. Após a exclusão das notícias repetidas, compuseram a amostra 71 documentos. Os dados foram analisados por meio da técnica análise de conteúdo, com apoio do software webQDA.

\section{Resultado(s)}

Foram identificados conteúdos referentes ao conceito do Transtorno do Espectro Autista; dados de prevalência; sintomas; fatores de risco; diagnóstico; tratamento; relação com altas habilidades; legislação específica; ações inclusivas; violação de direitos; experiências com arte e cultura; serviços voltados para o público autista; campanhas; capacitações para pais e profissionais; e relatos de experiências de pais e mães de crianças com o transtorno, diante do diagnóstico dos seus filhos e dos desafios do cotidiano familiar, destacando-se como o assunto mais abordado.

\section{Conclusão (ões)}

Os resultados indicam que revistas de circulação nacional voltadas para pais e mães, com foco no desenvolvimento infantil, podem ser uma relevante fonte de informação para esclarecer diversos aspectos relativos ao Transtorno do Espectro 
$4^{\circ}$ Congresso

Internacional

Sabará

13 a 15 de

setembro de 2018

Hotel Maksoud Plaza
Alameda Campinas, 150
Săo Paulo - Brasil

Autista, auxiliando seu reconhecimento precoce, dirimindo dúvidas recorrentes e compartilhando experiências, contribuindo, portanto, para a promoção da saúde mental infantil. 